\title{
ANALISIS PERKEMBANGAN LIKUIDITAS DAN RENTABILITAS PADA CV. MENDIHO
}

\author{
Jasasila $^{1}$
}

\begin{abstract}
The purpose of this research is to know and analyze the development of Liquidity and Rentability tingat on CV. Mendiho 2012-2016, the analysis used to see the level of Liquidity indicator used: Curent Ratio, Quick Ratio and Cash Ratio while for Rentability used indicator: Net Profit Margin, Return on Investment and Return On Equity. From the analysis results obtained that CV. Mendiho is able to meet its short-term liabilities (Liquidity) with the average of each indicator: Curent Ratio 555.46\%, Quick Ratio (450.93\%) and Cash Ratio (299.94\%), which is above average which has been set, although the developments that occur for each indicator is very volatile. For Rentability $C V$. Mendiho is also able to obtain maximum profitability (Rentability), with each indicator average: Net Profit Margin with average $51.17 \%$, Return On Investment (90.06\%) and Return On Equty (544,53\%) and developments for each indicator are also very volatile.
\end{abstract}

Keywords: Liquidity, Profitability

\section{PENDAHULUAN}

Laporan keuangan menyajikan laporan keaktifan suatu perusahaan serta kinerja perusahaan tersebut dalam menghasilkan keuntungan. Posisi keuangan perusahaan ditunjukkan dalam laporan Neraca dan laporan rugi laba. Dalam laporan neraca tersebut kita dapat mengetahui kekayaan atau aset perusahaan yang dimiliki (aktiva) dan pada sisi pasiva dapat kita ketahui dari mana dana untuk membiayai aktiva tersebut kita peroleh. Sedangkan kinerja perusahaan dalam menghasilkan laba dapat kita ketahui dri laporan rugi laba yang diterbitkan oleh perusahaan. Perkembangan posisi keuangan mempunyai arti yang sangat penting bagi perusahaan. Untuk melihat sehat tidaknya suatu perusahaan tidak hanya dapat dinilai dari keadaan fisiknya saja, misalnya dilihat dari gedung, pembangunan atau ekspansi. Faktor terpenting untuk dapat melihat perkembangan suatu perusahaan terletak dalam unsur keuangannya, karena dari unsur tersebut juga dapat mengevaluasi

${ }^{1}$ STIE Graha Karya Muara Bulian apakah kebijakan yang ditempuh suatu perusahaan sudah tepat atau belum, mengingat sudah begitu kompleksnya permasalahan yang dapat menyebabkan kebangkrutan dikarenakan banyaknya perusahaan yang akhirnya gulung tikar karena faktor keuangan yang tidak sehat. Dengan keadaan sekarang ini, dimana persaingan ketat dibidang perekonomian sudah mulai masuk ke negara Indonesia, maka jika seorang manajer perusahaan tidak memperhatikan faktor kesehatan keuangan dalam perusahaannya, mungkin saja akan terjadi kebangkrutan seperti yang telah dikemukakan sebelumnya. Analisis keuangan pada dasarnya ingin melihat prospek dan risiko perusahaan. Prospek bisa dilihat dari tingkat keuntungan (profitabilitas) dan risiko bisa dilihat dari kemungkinan perusahaan mengalami kesulitan keuangan atau mengalami kebangkrutan. (Mamduh M. Hanafi, 2005:21). Untuk menghindari kebangkrutan tersebut maka seorang manajer perusahaan sangat penting untuk selalu berusaha agar perusahaannya dapat terus berjalan atau dengan kata lain manajer 
tersebut dapat menjaga kelangsungan hidup perusahaannya yang ditempuh dengan cara selalu memperhatikan dan mengadakan evaluasi terhadap perkembangan perusahaannya dari waktu ke waktu. Seorang manajer harus dapat memahami kondisi keuangan perusahaannya, karena pada dasarnya kondisi keuangan tersebut akan mempengaruhi kelangsungan hidup perusahaannya secara keseluruhan. Salah satu alat yang dipakai untuk mengetahui kondisi keuangan, dalam hal ini tingkat kesehatan suatu perusahaan adalah berwujud laporan keuangan yang disusun pada setiap akhir periode yang berisi pertanggungjawaban dalam bidang keuangan atas berjalannya suatu usaha. Laporan finansial merupakan hasil dari proses akuntansi yang dapat digunakan sebagai alat berkomunikasi antara data finansial atau aktivitas suatu perusahaan dengan pihak-pihak lain yang berkepentingan dengan data atau aktivitas tersebut. (S. Munawir, 1997:2). Data finansial yang dimaksud adalah data yang tercermin dalam suatu laporan finansial, yang memberikan gambaran tentang keuangan suatu perusahaan, yang terdiri dari Neraca, Laporan Rugi Laba serta laporanlaporan keuangan lainnya. Dengan mengadakan analisa terhadap pos-pos neraca akan dapat diketahui atau akan diperoleh gambaran tentang posisi keuangannya, sedangkan analisa terhadap laporan rugi labanya akan memberikan gambaran tentang hasil atau perkembangan usaha perusahaan yang bersangkutan (S. Munawir, 1997:1). Untuk mengukur tingkat kesehatan keuangan perusahaan dapat digunakan alat analisis yang disebut analisis rasio keuangan. Untuk melakukan analisis rasio keuangan, diperlukan perhitungan rasio-rasio keuangan yang mencerminkan aspekaspek tertentu. Rasio-rasio keuangan mungkin dihitung berdasarkan atas angka-angka yang ada dalam neraca saja, dalam laporan rugi-laba saja, atau pada neraca dan laporan rugi-laba. Setiap analisis keuangan bisa saja merumuskan rasio tertentu yang dianggap mencerminkan aspek tertentu (Suad Husnan, 2002:69). Rasio keuangan merupakan alat yang dinyatakan dalam artian relative maupun absolute yang menjelaskan hubungan tertentu antara angka yang satu dengan angka yang lainnya dalam laporan keuangan (Syafaruddin Alwi, 1994:107). Analisis laporan keuangan akan memberikan hasil yang terbaik jika digunakan dalam suatu kombinasi untuk menunjukan suatu perubahan kondisi keuangan atau kinerja operasional selama periode tertentu, lebih lanjut dapat memberikan gambaran suatu trend dan pola perubahan, yang pada akirnya bisa memberikan indikasi adanya risiko dan peluang bisnis (Mudrajad Kuncoro dan Suhardjono, 2002:557).

CV. Mendiho salah satu perusahaan percetakan dan pengadaan barang yang berlokasi di Komplek BBC No. A14 Muara Bulian, merupakan salah satu perusahaan yang harus mampu menilai kemampuan keuangan melalui penilain kinerja keuangannya, pada dasarnya penilaian kinerja keuangan yang dilakukan CV. Mendiho ini bertujuan untuk mengevaluasi kinerja keuangan pada masa yang lalu, dengan melakukan berbagai analisis, sehingga diperoleh posisi keuangan perusahaan yang mewakili realitas perusahaan dan potensi kinerja yang akan berlanjut. Secara umum tujuan utama rasio keuangan digunakan adalah untuk menilai kemampuan perusahaan dalam memenuhi kewajibannya, namun disamping itu dari rasio likuiditas dapat diketahui hal- hal lain yang lebih spesifik yang juga masih berkaitan dengan kemampuan perusahaan dalam memenuhi kewajibannya. Semua ini 
tergantung dari jenis rasio likuiditas yang digunakan. Dalam praktiknya, untuk mengukur rasio keuangan secara lengkap, dapat menggunakan jenisjenis rasio likuiditas yang ada.

Likuiditas perusahaan menggambarkan kemampuan perusahaan tersebut dalam memenuhi kewajiban jangka pendeknya kepada kreditor jangka pendek. Dalam penelitian ini Untuk mengukur kemampuan perusahaan penulis menggunakan Cash ratio dengan standar kemampuan memenuhi kewajiban jangka pendek $100 \%$, curent ratio $(200 \%)$ dan Quick ratio $(100 \%)$ :

\begin{tabular}{ccc}
\hline No & $\begin{array}{c}\text { Rasio } \\
\text { Likuiditas }\end{array}$ & Standar \\
\hline 1 & Cash Ratio & $100 \%$ \\
2 & Curent Ratio & $200 \%$ \\
3 & Quick Ratio & $100 \%$ \\
\hline
\end{tabular}

Sedangkan untuk mengukur tingkat keuntungan suatu perusahaan digunakan rasio keuntungan atau profitabilitas yang dikenal juga dengan nama rasio rentabilitas. Sesuai dengan tujuan perusahaan yang hendak dicapai terdapat beberapa jenis rasio rentabilitas yang dapat digunakan yaitu ; Profit margin, Return On Investmen dan Return On Equity. Masing-masing untuk menilai serta mengukur posisi keuangan perusahaan dalam suatu periode tertentu atau untuk beberapa periode. Dalam prakteknya jenis-jenis rasio rentabilitas yang dapat digunakan adalah :

\begin{tabular}{ccc}
\hline No & Rasio Rentabilitas & Standar \\
\hline 1 & Net Profit Margin & $30 \%$ \\
2 & $\begin{array}{c}\text { Return On } \\
\text { Investment }\end{array}$ & $30 \%$ \\
3 & Return On Equity & $30 \%$ \\
\hline
\end{tabular}

\section{Curent Ratio}

Dilihat pentingnya manfaat dari analisis likuiditas dan rentabilitas suatu perusahaan bagi pihak intern maupun pihak ekstern perusahaan serta ditunjang data-data dan teori yang selama ini didapat, maka penulis tertarik untuk melakukan penelitian yang berjudul "Analisis Perkembangan Likuditas dan Rentabilitas pada $C V$. Mendiho".

Dari uraian latar belakang diatas maka dapat dirumuskan masalah penelitian yaitu : Bagaimana perkembangan tingkat likuiditas dan rentabilitas pada CV Mendiho, sehingga tujuan dari penelitian ini adalah: 1) Untuk mengetahui dan menganalisis perkembangan tingat likuiditas pada CV. Mendiho 20122016; 2) Untuk mengetahui dan menganalisis perkembangan tingat rentabilitas pada CV. Mendiho 20122016

\section{METODE PENELITIAN}

Objek penelitian ini adalah $\mathrm{CV}$. Mendiho yang berlokasi di Komplek BBC Nomor A.14 Muara Bulian Batanghari, CV. Mendiho adalah perusahaan yang bergerak dibidang percetakan dan perdagangan berdiri sejak tahun 2009. Dalam pengumpulan data penulis lansung ke objek penelitian dan melalui studi kepustakaan, sedangkan jenis data yang digunakan dalam penelitian ini adalah data primer dan data sekunder. Untuk mengukur rasio likuiditas maka digunakan alat analisis :

2. Quick Ratio

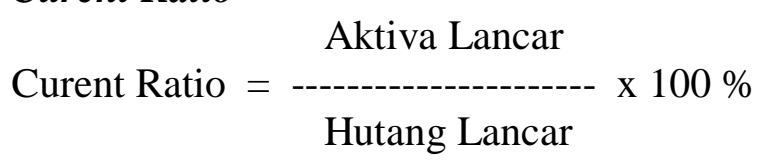

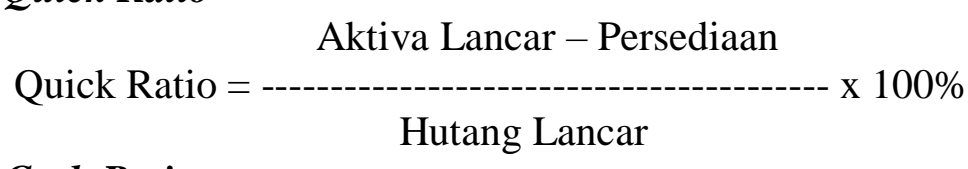

\section{Cash Ratio}

Kas 


$$
\begin{aligned}
\text { Cash Ratio }= & --------------------~ \\
& \text { x 100\% }
\end{aligned}
$$

Sedangkan untuk menghitung (ROI) dan Return on Equity (ROE) rasio rentabilitas yang terdiri dari digunakan rumus sebagai berikut: profit margin, Returt on Investment

\section{Profit Margin}

Laba Bersih sesudah pajak (EAIT)

Profit Margin = ---------------------------------- x 100\%

\section{Return On Investment}

$$
\text { Penjualan }
$$

Laba Bersih sesudah pajak (EAIT)

\section{Return on Equity}

$$
\text { Total Aktiva }
$$

$$
\text { X } 100 \%
$$

Laba Bersih sesudah pajak (EAIT)

$$
\text { ROE = ----------------------------------- x 100\% }
$$

Ekuitas

Untuk mengetahui kecendrungan naik atau turunnya kinerja keuangan suatu perusahan maka diukur dengan

$$
\mathrm{Ta}-\mathrm{Td}
$$

$$
\text { Perkembangan }=-\frac{---------------~}{} \text { x 100\% }
$$

Dimana :

$\mathrm{Ta}=$ Tahun Analisis

$\mathrm{Td}=$ Tahun Dasar

\section{HASIL PEMBAHASAN}

\section{Analisis Perkembangan Likuditas}

\begin{tabular}{|c|c|c|c|c|}
\hline Tahun & $\begin{array}{c}\text { Aktiva Lancar } \\
\text { (Rp) }\end{array}$ & $\begin{array}{c}\text { Hutang Lancar } \\
\text { (Rp) }\end{array}$ & $\begin{array}{c}\text { Curent Ratio } \\
(\%)\end{array}$ & $\begin{array}{c}\text { Perkembangan } \\
\%\end{array}$ \\
\hline 2012 & 80.600 .000 & 9.000 .000 & $895,56 \%$ & 0 \\
\hline 2013 & 102.200 .000 & 34.500 .000 & $296,23 \%$ & $-66,92 \%$ \\
\hline 2014 & 107.800 .000 & 22.200 .000 & $485,59 \%$ & $63,92 \%$ \\
\hline 2015 & 136.000 .000 & 27.000 .000 & $503,70 \%$ & $3,73 \%$ \\
\hline 2016 & 160.000 .000 & 26.835 .000 & $596,24 \%$ & $18,37 \%$ \\
\hline \multicolumn{3}{|c|}{ Rata-rata } & $555,46 \%$ & \\
\hline
\end{tabular}

Rasio likuiditas menunjukkan seberapa besar kemampuan untuk memenuhi kewajiban jangka menggunakan rumus perkembangan, yaitu :

Perkembangan Curent ratio pada CV. Mendiho 2012-2016 :

Dari perhitungan tabel diatas dapat dijelaskan bahwa, rata-ra Curent Ratio CV. Mendiho tahun 2012-2016 adalah $555,46 \%$ artinya melebihi standar yang ditetapkan yaitu $200 \%$, artinya CV. Mendiho sudah mampu memenuhi kewajiban jangka pendeknya. Hal ini dapat dilihat pada pendeknya ( hutang lancar ) pada saat jatuh tempo, untuk menganalisis perkembangan Rasio likuiditas dengan menggunakan alat analisis Curent Ratio, Quick Ratio dan Cash ratio dapat dijelaskan sebagai berikut :

\section{Curent Ratio}

tahun 2012 CV. Mendiho memiliki aktiva lancar sejumlah Rp. 80.600.000,- dan hutang lancar Rp. 9.000.000,- sedangkan curent ratio perusahaan sebesar 895,56\%, ini berarti setiap Rp. 1,- hutang lancar yang dimiliki oleh CV. Mendiho dapat dijamin oleh Rp. 8,96 aktiva lancar. 
Untuk tahun 2013 curent ratio CV. Mendiho senilai 296,23\% yang artinya setiap Rp. 1,- hutang lancar dapat dijamin oleh Rp. 2,96,- aktiva lancar, begitu juga pada tahun 2014 dengan curent ratio sebesar $485,59 \%$, setiap hutang lancar Rp. 1,- pada tahun 2014, mampu dijamin oleh Rp. 4,86,- Aktiva lancar. Begitu juga ada tahun 2015 setiap Rp. 1,- hutang lancar mampu dijamin Rp. 5,03,- Aktiva lancar pada tahun tersebut. Sedangkan pada tahun 2016 dengan tingkat curent ratio $596,24 \%$ yang artinya setiap Rp. 1,hutang lancar dapat dijamin oleh Rp. 5,96,- Aktiva lancar. Perkembangan curent ratio dari tahun 2012-2016 pada CV. Mendiho terjadi fluktuatif, dimana pada tahun 2013 terjadi penurunan sebesar 66,92\% ini diakibatkan kenaikan hutang lancar yang signifikan pada tahun 2013 jika dibandingkan dengan tahun 2012. Tetapi pada tahun 2014 terjadi peningkatan curent ratio sebesar $63,92 \%$ dikarenakan terjadi kenaikan aktiva lancar yang diiringi dengan penurunan hutang lancar pada Berikut tabel perkembangan Quick

\begin{tabular}{ccccc}
\multicolumn{5}{c}{ Berikut tabel perkembangan Quick ratio CV. Mendiho tahun 2012-2016 : } \\
\hline \multirow{2}{*}{ Tahun } & $\begin{array}{c}\text { Aktiva Lancar - } \\
\text { Persediaan (Rp) }\end{array}$ & $\begin{array}{c}\text { Hutang Lancar } \\
\text { (Rp) }\end{array}$ & $\begin{array}{c}\text { Curent Ratio } \\
(\mathbf{\%})\end{array}$ & $\begin{array}{c}\text { Perkembangan } \\
\text { \% }\end{array}$ \\
\hline 2012 & 64.200 .000 & 9.000 .000 & $713,33 \%$ & \\
2013 & 84.200 .000 & 34.500 .000 & $244,06 \%$ & $-65,79 \%$ \\
2014 & 90.000 .000 & 22.200 .000 & $405,41 \%$ & $66,11 \%$ \\
2015 & 110.000 .000 & 27.000 .000 & $407,41 \%$ & $0,49 \%$ \\
2016 & 130.000 .000 & 26.835 .000 & $484,44 \%$ & $18,91 \%$ \\
\multicolumn{5}{c}{ Rata-rata } \\
\hline
\end{tabular}

Dari perhitungan tabel diatas dapat dijelaskan bahwa, rata-rata Quick Ratio CV. Mendiho tahun 2012-2016 adalah $450,93 \%$ artinya melebihi standar yang ditetapkan yaitu $100 \%$, artinya CV. Mendiho sudah mampu memenuhi kewajiban finansialnya yang lebih liquid pada saat jatuh tempo, quick ratio terkecil pada tahun 2013, dimana hutang lancar mengalami peningkatan yang cukup besar, sedangkan quick rasio terbesar pada tahun 2012 dimana terjadi peningkatan nilai Aktiva lancar - persediaan yang tahun 2014. Untuk tahun 2015 kenaikan curent ratio tidak terlalu signifikan yaitu sebesar $3,73 \%$ jika dibandingkan dengan tahun sebelumnya, namun pada tahun 2016 perkembangan curent ratio mengalami peningatan yang cukup siginifikan jika dibandingkan dengan tahun sebelumnya yaitu sebesar $18,37 \%$.

\section{Quick Ratio}

Quick ratio digunakan untuk mengukur kemampuan perusahaan memenuhi kewajiban finansialnya atas aktiva yang paling liquid. Semakin besar ratio semakin besar kemampuan perusahaan memenuhi kewajiban finansialnya. Jika Quick ratio diatas standar yang berlaku maka perusahaan dapat dikatakan lebih baik dari perusahaan lain yang berada dibawah standar, kondidi ini menunjukkan bahwa perusahaan tidak harus menjual persediaan jika hendak melunasi hutang lansar, tetapi dapat menjual surat berharga atau penagihan piutang. 
hutang lancar dapat dijamin oleh Rp. 2,44,- aktiva lancar dikurang persediaan, begitu juga pada tahun 2014 dengan curent ratio sebesar $405,41 \%$, setiap hutang lancar Rp. 1,pada tahun 2014, mampu dijamin oleh Rp. 4,05,- Aktiva lancar dikurangi dengan persediaan. Begitu juga ada tahun 2015 setiap Rp. 1,- hutang lancar mampu dijamin oleh Rp. 4,07,- Aktiva lancar dikurang persediaan pada tahun tersebut. Sedangkan pada tahun 2016 dengan tingkat curent ratio $484,44 \%$ yang artinya setiap Rp. 1,- hutang lancar dapat dijamin oleh Rp. 4,84,Aktiva lancar dikurangi dengan persediaan. Perkembangan quick ratio dari tahun 2012-2016 pada CV. Mendiho terjadi fluktuatif, dimana pada tahun 2013 terjadi penurunan

sebesar $65,79 \%$ ini diakibatkan kenaikan hutang lancar yang signifikan pada tahun 2013 jika dibandingkan dengan tahun 2012. Tetapi pada tahun 2014 terjadi peningkatan quick ratio sebesar $66,11 \%$ dikarenakan terjadi kenaikan aktiva lancar yang dikurangi persediaan yang diiringi dengan penurunan hutang lancar pada tahun 2014. Untuk tahun 2015 kenaikan quick ratio tidak terlalu signifikan yaitu sebesar $0,49 \%$ jika dibandingkan dengan tahun sebelumnya, namun pada tahun 2016 perkembangan quick ratio mengalami peningatan yang cukup siginifikan jika dibandingkan dengan tahun sebelumnya yaitu sebesar $18,91 \%$.

\section{Cash Ratio}

Tabel perkembangan cash rasio CV. Mendiho tahun 2012-2016

\begin{tabular}{ccccc}
\hline Tahun & $\begin{array}{c}\text { Kas } \\
(\mathbf{R p})\end{array}$ & $\begin{array}{c}\text { Hutang Lancar } \\
(\mathbf{R p})\end{array}$ & $\begin{array}{c}\text { Curent Ratio } \\
(\boldsymbol{\%})\end{array}$ & $\begin{array}{c}\text { Perkembangan } \\
\mathbf{\%}\end{array}$ \\
\hline 2012 & 42.000 .000 & 9.000 .000 & $466,67 \%$ & \\
2013 & 58.000 .000 & 34.500 .000 & $168,12 \%$ & $-63,98 \%$ \\
2014 & 60.000 .000 & 22.200 .000 & $270,27 \%$ & $60,76 \%$ \\
2015 & 70.000 .000 & 27.000 .000 & $259,26 \%$ & $-4,07 \%$ \\
2016 & 90.000 .000 & 26.835 .000 & $335,38 \%$ & $29,36 \%$ \\
& Rata-rata & & $\mathbf{2 9 9 , 9 4 \%}$ & \\
\hline
\end{tabular}

Dilihat dari hasil perhitungan tabel diatas bahwa, rata-rata Cash Ratio CV. Mendiho tahun 2012-2016 adalah 299,94\% menunjukkan Cash ratio melebihi standar yang ditetapkan yaitu $100 \%$, artinya CV. Mendiho sudah mampu memenuhi kewajiban hutang jangka pendeknya, quick ratio terkecil pada tahun 2013, dimana hutang lancar mengalami peningkatan yang cukup besar, sedangkan quick rasio terbesar pada tahun 2012 dimana nilai kas yang besar. Setiap tahunnya $\mathrm{CV}$. Mendiho mempunyai kemampuan menutupi hutang jangka pendeknya, hal ini dapat dilihat pada tahun 2012 CV. Mendiho memiliki kas sejumlah Rp. 42.000.000,- dan hutang lancar Rp. 9.000.000,- sedangkan cash ratio perusahaan sebesar 466,67\%, ini berarti setiap Rp. 1,- hutang lancar yang dimiliki oleh CV. Mendiho mampu ditutupi atau dijamin oleh Rp. 4,67,- asset kas. Untuk tahun 2013 cash ratio CV. Mendiho senilai 168,12\% yang artinya setiap Rp. 1,- hutang lancar dapat dijamin oleh Rp. 1,68,asset kas, begitu juga pada tahun 2014 dengan cash ratio sebesar 270,27\%, setiap hutang lancar Rp. 1,- pada tahun 2014, mampu dijamin oleh Rp. 2,70,asset kas. Demikian pula pada tahun 2015 setiap Rp. 1,- hutang lancar mampu dijamin oleh Rp. 2,59,- kas asset pada tahun tersebut. Sedangkan pada tahun 2016 dengan tingkat cash ratio 335,38\% yang artinya setiap $\mathrm{Rp}$. 1,- hutang lancar dapat dijamin oleh Rp. 3,35,- kas asset. Untuk perkembangan cash ratio dari tahun 2012-2016 pada CV. Mendiho terjadi sangat fluktuatif, dimana pada tahun 
2013 terjadi penurunan sebesar $63,98 \%$ ini diakibatkan kenaikan hutang lancar yang signifikan pada tahun 2013 jika dibandingkan dengan tahun 2012. Tetapi pada tahun 2014 terjadi peningkatan quick ratio dari tahun sebelumnyasebesar $\quad 60,76 \%$ dikarenakan terjadi kenaikan kas asset yang diiringi dengan penurunan hutang lancar pada tahun 2014. Pada tahun 2015 kembali terjadi penurunan cash ratio yaitu sebesar $-4,07 \%$ jika dibandingkan dengan tahun sebelumnya, namun pada tahun 2016 perkembangan cash ratio mengalami

peningatan yang cukup siginifikan jika dibandingkan dengan tahun sebelumnya yaitu sebesar $29,36 \%$.

\section{Analisis Perkembangan Rentabilitas Net Profit Margin}

Merupakan rasio yang membandingkan antara laba bersih sesudah pajak dengan penjualan bersih, rasio ini digunakan untuk mengukur kemampuan perusahaan untuk memperoleh laba atas volume penjualan, semakin tinggi Net profit Margin semakin baik kegiatan operasional perusahan.

\begin{tabular}{cccrc}
\hline Tahun & $\begin{array}{c}\text { EAIT } \\
\text { (Rp) }\end{array}$ & Penjualan (Rp) & $\begin{array}{c}\text { Net profit } \\
\text { Margin \% }\end{array}$ & $\begin{array}{c}\text { Perkembangan } \\
\text { \% }\end{array}$ \\
\hline 2012 & 128.600 .000 & 246.000 .000 & $52,28 \%$ & \\
2013 & 149.800 .000 & 284.250 .000 & $52,70 \%$ & $0,81 \%$ \\
2014 & 153.400 .000 & 291.900 .000 & $52,55 \%$ & $-0,28 \%$ \\
2015 & 161.000 .000 & 338.250 .000 & $47,60 \%$ & $-9,43 \%$ \\
2016 & 184.620 .000 & 363.915 .000 & $50,73 \%$ & $6,58 \%$ \\
\multicolumn{5}{c}{ Rata-rata } \\
\hline
\end{tabular}

Dari tabel diatas dapat dijelaskan bahwa pada tahun 2012 sampai dengan tahun 2016, CV.Mendiho telah mampu melebihi standar yang ditetapkan atau Net Profit Margin diatas 30\%, ini menunjukkan bahwa CV. Mendiho dapat menjalankan kegiatan usahanya dengan baik. Dapat dijelaskan dengan rincian sebagai berikut, tahun 2012 laba bersih setelah pajak (EAIT) adalah Rp. 128.600.000,- dengan jumlah penjualan Rp. 246.000.000,- dan keuntungan (laba) 52,28\%, pada tahun 2013 dengan EAIT Rp. 149.800.000,dan penjualan Rp. 248.250.000,sehingga didapat laba sebesar 52,70\%, sedankan pada tahun 2014 EAIT yang dimiliki oleh CV. Mendiho adalah Rp. 153.400.000,- dengan penjualan Rp. 291.900.000,- dan keuntungan (laba) $52,55 \%$. Demikian juga pada tahun 2015 dengan EAIT Rp. 161.000.000,penjualan Rp. 338.250.000,- CV. Mendiho mendapatkan keuntunga sebesar 47,60\%, pada tahun 2016 EAIT $\mathrm{CV}$. Mendiho meningkat menjadi
Rp.184.620.000,- dan penjualan $\mathrm{Rp}$. 363.915.000,-Sehingga perkembangan selama periode tersebut sangat fluktuatif dimana perkembangan Net Profit Margin pada tahun 2013 terjadi peningatan dari tahun sebelumnya sebesar $0,81 \%$, pada tahun 2014 NPM mengalami penurunan sebesar $0,28 \%$, penurunan ini diakibatkan adanya pesaing baru pada usaha yang sejenis sehingga menurunkan penjualan pada tahun tersebut. dan pada tahun 2015 kembali terjadi penurunan yang sangat signifikan yaitu $9,43 \%$, pada tahun ini CV. Mendiho dihadapi besarnya pengeluaran yang harus dibayarkan serta beban hutang perusahaan yang harus dibayarkan tetapi pada tahun 2016 pemilik perusahan melakukan metode baru dalam usahanya dengan melakukan promosi dan kerjasama dengan instansi pemerintah, disamping itu CV. Mendiho juga menambah produk-produk baru baik produk Percetakan maupun produk pengadaaan 
untuk meningatan daya beli konsumen, metode tersebut mampu meninkatkan NPM dari tahun sebelumnya yaitu Return On Investment (ROI) sebesar $6,58 \%$.

Perkembangan Net Margin Profit CV. Mendiho tahun 2012-2016

\begin{tabular}{cccrc}
\hline Tahun & $\begin{array}{c}\text { EAIT } \\
(\mathbf{R p})\end{array}$ & $\begin{array}{c}\text { Total Aktiva } \\
(\mathbf{R p})\end{array}$ & ROI \% & $\begin{array}{c}\text { Perkembangan } \\
\mathbf{\%}\end{array}$ \\
\hline 2012 & 128.600 .000 & 123.450 .000 & $104,17 \%$ & \\
2013 & 149.800 .000 & 183.150 .000 & $81,79 \%$ & $-21,48 \%$ \\
2014 & 153.400 .000 & 167.250 .000 & $91,72 \%$ & $12,14 \%$ \\
2015 & 161.000 .000 & 189.750 .000 & $84,85 \%$ & $-7,49 \%$ \\
2016 & 184.620 .000 & 210.300 .000 & $87,79 \%$ & $3,47 \%$ \\
& Rata-rata & & $\mathbf{9 0 , 0 6 \%}$ & \\
\hline \multicolumn{5}{c}{} \\
\hline
\end{tabular}

Dari tabel diatas dapat dijelaskan bahwa pada tahun 2012 sampai dengan tahun 2016, tingkat pengembalian investasi CV.Mendiho telah mampu melebihi standar yang ditetapkan atau Return Om Imvestment (ROI) diatas $30 \%$, ini menunjukkan bahwa tingkat pengembalian investasi CV.Mendiho sudah sangat baik. Dapat dijelaskan dengan rincian sebagai berikut, tahun 2012 laba bersih setelah pajak (EAIT) adalah Rp. 128.600.000,- dan total aktiva Rp.123.450.000,- dengan tingkat pengembalian investasi (ROI) $104,17 \%$, pada tahun 2013 dengan EAIT Rp. 149.800.000,- dan total aktiva Rp. 183.150.000,- sehingga didapat ROI sebesar 81,79\%, sedangkan pada tahun 2014 EAIT yang dimiliki oleh CV. Mendiho adalah Rp. 153.400.000,- dengan total aktiva Rp. 167.250.000,- yang menghasilkan ROI $91,72 \%$. Demikian juga pada tahun 2015 dengan EAIT Rp. 161.000.000,Perkembangan ROE CV. Mendiho 2012-2016

\begin{tabular}{ccccr}
\hline Tahun & $\begin{array}{c}\text { EAIT } \\
(\mathbf{R p})\end{array}$ & $\begin{array}{c}\text { Equity } \\
(\mathbf{R p})\end{array}$ & $\begin{array}{c}\text { ROE } \\
\mathbf{\%}\end{array}$ & $\begin{array}{c}\text { Perkembangan } \\
\mathbf{\%}\end{array}$ \\
\hline 2012 & 128.600 .000 & 18.000 .000 & $714,44 \%$ & \\
2013 & 149.800 .000 & 21.300 .000 & $703,29 \%$ & $-1,56 \%$ \\
2014 & 153.400 .000 & 30.000 .000 & $51,33 \%$ & $-27,29 \%$ \\
2015 & 161.000 .000 & 42.000 .000 & $383,33 \%$ & $-25,03 \%$ \\
2016 & 184.620 .000 & 45.000 .000 & $410,27 \%$ & $7,03 \%$ \\
\multicolumn{5}{c}{ Rata-rata } \\
\hline
\end{tabular}

Dari tabel diatas dapat dijelaskan bahwa pada tahun 2012 sampai dengan tahun 2016, rata-rata kemampuan total aktiva Rp.189.750.000,- dengan hasil ROI sebesar $84,85 \%$, pada tahun 2016 EAIT CV. Mendiho meningkat menjadi Rp.184.620.000,- dan total aktiva Rp. 210.300.000,- Sehingga perkembangan selama periode tersebut sangat fluktuatif dimana perkembangan ROI pada tahun 2013 terjadi penurunan dari tahun sebelumnya sebesar $21,48 \%$, penurunan ini disebabkan oleh naiknya total aktiva dari tahun sebelumnya, pada tahun 2014 perkembangan ROI mengalami peningkatan sebesar $12,14 \% \%$, salah satau faktor yang mempunyai kontribusi menaikkan ROI pada tahun ini adalah dengan turunnya total aktiva dari tahun sebelumnya dan pada tahun 2015 kembali terjadi penurunan sebesar 7,49\% dari tahun sebelumnya kemudian pada tahun 2016 terjadi peningkatan sejumlah $3,47 \%$ dari tahun sebelumnya $9,43 \%$.

Perkembangan Return On Equity perusahaan (CV.Mendiho) untuk memperoleh laba bersih atas modal sendiri telah melebihi standar yang 
ditetapkan atau Return On Equity ( $R O E$ ) diatas $30 \%$, ini menunjukkan bahwa tingkat perolehan laba atas modal sendiri CV.Mendiho sudah sangat baik. Dapat dijelaskan dengan rincian sebagai berikut, tahun 2012 laba bersih setelah pajak (EAIT) adalah Rp. 128.600.000,- dan Equity Rp.18.000.000,- dengan tingkat ROE $714,44 \%$, pada tahun 2013 dengan EAIT Rp.149.800.000,- dan Equity Rp. 21.300.000,- sehingga didapat ROE sebesar $703,29 \%$ atau terjadi penurunan $1,56 \%$ dari tahun seblumnya, sedangkan pada tahun 2014 EAIT yang dimiliki oleh CV. Mendiho adalah Rp. 153.400.000,- dengan Equity Rp.30.000.000,- yang menghasilkan ROE $511,33 \%$ atau terjadi penurunan $27,29 \%$ dari tahun 2013 Demikian juga pada tahun 2015 dengan EAIT Rp. 161.000.000,- dan Equity Rp.42.000.000,- dengan hasil ROE sebesar $383,33 \%$ pada tahun ini perkembangan ROE kembali terjadi penurunan jika dibandingkan dengan tahun sebelumnya, tetapi pada tahun 2016 EAIT CV. Mendiho meningkat menjadi Rp.184.620.000,- dan Equity Rp.45.000.000,- dengan ROE 410,27\% atau terjadi peningkatan sebesar 7,03\% dari tahun sebelumnya. Sehingga perkembangan selama periode tersebut dapat dikatakan sangat fluktuatif.

\section{SIMPULAN}

Perkembangan Likuiditas CV. Mendiho selama lima tahun terakhir 2012-2016 dengan menggunakan indikator Curent Ratio dengan rata-rata $555,46 \%$, Quick Ratio $(450,93 \%)$ dan Cash Ratio ( 299,94\%), dengan ratarata yang berada diatas standar yang sudah ditentukan untuk masingmasing indikator menunjukkan bahwa CV. Mendiho sudah mampu menyelesaikan kewajiban jangka pendeknya terutama yang berhubungan dengan Aktiva Lancar, Aktiva lancar yang dikurangi persediaan dan kemampuan kas yang dimiliki oleh perusahaan. Perkembangan yang fluktuatif selama lima tahun terakhir 2012-2016 untuk masing-msing indikator pada umumnya dipengaruhi oleh kenaikan dan penurunan aktiva yang diiiringi dengan hutang lancar yang dimiliki oleh perusahaan.

Sedangkan untuk Rentabilitas CV. Mendiho selama lima tahun terakhir 2012-2016 dengan indikator Net Profit Margin dengan rata-ratanya 51,17\%, Return On Invesment (90,06\%) dan Return On Equty $(544,53 \%)$. Rata-rata masing-masing indikator tersebut adalah rata-rata diatas standar yang telah ditetapkan, artinya CV. Mendiho mampu mendapatkan keuntungan dan laba yang cukup maksimal terutama dari indikator, Penjulaan, Total Aktiva dan Equity (modal sendiri). Perkembangan masing-masing indikator yang sangat fluktuatif dipengaruhi oleh kemampuan pemilik perusahaan dalam mengelola manajemen keuangan yang ada sehingga dapat mengatur dan mengendalikan biaya-biaya baik pengeluaran maupun setiapt tahunnya.

\section{DAFTAR PUSTAKA}

Ernawati. 2003. Pengukuran Kinerja Perusahaan Ditinjau dari Analisis Rasio Keuangan, Skripsi. Fakultas Ekonomi UMS, Tidak Dipublikasikan.

Ikatan Akuntansi Indonesia. 2007. Standar Akuntansi Keuangan, Jakarta: Salemba Empat.

Indah Kurniawati. 2001. Perbandingan Rasio-Rasio Keuangan pada Perusahaan Besar dan Perusahaan Kecil Di Malaysia, Singapura, dan Taiwan. Jurnal Akuntansi dan Bisnis. Vol. 1, No. $1: 13-23$.

Mabruroh. 2004. Manfaat dan Pengaruh Rasio Keuangan dalam Knalisis Kinerja 
Keuangan Perbankan. Benefit.

Vol. 8, No. $1: 37-51$.

Mamduh M. Hanafi. 2005. Analisis Laporan Keuangan, Edisi Kedua. Yogyakarta: UPP AMP YKPN. Menteri Keuangan Republik Indonesia. 1992.

Retno Tri Setyowati. 2008. Analisis Rasio Keuangan untuk Menilai Kinerja Perusahaan Consumer Goods, Skripsi. Fakultas Ekonomi UMS, Tidak Dipublikasikan.

Sofyan Syafri Harahap. 2006. Analisis Kritis atas Laporan Keuangan, Edisi Kelima. Jakarta: PT Raja Grafindo Persada.

Suad Husnan. 2002. Dasar-Dasar Manajemen Keuangan, Edisi Ketiga. Yogyakarta: UPP AMP YKPN.

Bastian, Indra \& Suhardjono. 2006. Akuntansi Perbankan. Jakarta:Salemba Empat

Carl S. Warren, James M. Reeve, dan Philip E. Fess. 2006. Acounting Pengantar Akuntansi. Jakarta:

Salemba Empat Harnanto. 2002. Akuntansi Keuangan Menengah. Yogyakarta: BPFE-Yogyakarta

Kasmir. 2010. Analisis Laporan Keuangan. Jakarta: PT Raja Grafindo Persada

Kasmir. 2008. Manajemen Perbankan. Jakarta: PT Raja Grafindo Persada Mardiasmo. 